bahasa \& sastra, Vol. 14, No.1, April 2014

\title{
PEMBELAJARAN BAHASA ASING DI INDONESIA: ANTARA GLOBALISASI DAN HEGEMONI
}

\author{
Iman Santoso \\ Jurusan Pendidikan Bahasa Jerman \\ Fakultas Bahasa dan Seni, Universitas Negeri Yogyakarta \\ Korespondensi: Jln. Colombo No.1 Yogyakarta 5528 \\ Pos-el: iman_santoso@uny.ac.id
}

\begin{abstract}
Abstrak
Penyelenggaraan pembelajaran bahasa Asing di Indonesia merupakan upaya bagi bangsa Indonesia untuk bisa menyerap dan mengikuti perkembangan ilmu pengetahuan dan teknologi di dunia, sekaligus jalan untuk bisa masuk ke dalam masyarakat global. Di balik tujuan tersebut, terselip kekhawatiran adanya infiltrasi nilai-nilai Asing (Barat) yang dapat mengikis identitas pembelajar bahasa Asing sebagai bangsa Indonesia. Kekhawatiran ini muncul karena dalam pembelajaran bahasa Asing terkandung informasi mengenai budaya Asing (Barat) beserta nilai-nilai kulturalnya. Nilai-nilai kultural barat tersebut, jika tidak dipandang secara kritis oleh pengajar dan pembelajar bahasa Asing sangat mungkin mengubah pandangan kultural pembelajar di Indonesia. Pembelajaran bahasa Asing bahkan dicurigai menjadi sarana Barat untuk melakukan hegemoni terhadap bangsa Indonesia (Timur). Dalam artikel ini dipaparkan mengenai (1) situasi pembelajaran bahasa Asing di Indonesia, (2) bentuk-bentuk hegemoni "Barat" terhadap "Timur" melalui pembelajaran Bahasa Asing, (3) Alternatif bentuk pembelajaran bahasa Asing berbasis etnopedagogik dan interkultural.
\end{abstract}

Kata-Kata Kunci: Pembelajaran bahasa Asing, hegemoni, etnopedagogik, pembelajaran interkultural

\begin{abstract}
Foreign language learning in Indonesia constitutes an attempt for Indonesians to be able to absorp and keep up with the development of science and technology in the world, and to provide a way for Indonesian people to interact with other global members. On the other hand, there appears some concern that there may be infiltration of foreign values, especially from the West, that might weaken the learners'identities as Indonesians. This concern has emerged because foreign language learning generally presents Western elements of cultures and values. If it is not critically examined, these Western values are likely to change the learners " points of view of cultural values appropriate to be practised in their lives. Foreign language learning is also suspected as a means for the West to extend the Western hegemonies over the East such as Indonesians. This article explores a number of issues: (i) learning situations of foreign languages in Indonesia, (ii) Western hegemonic forms over the Eastern world through foreign language learning and (iii) alternative forms of foreign language learning based on ethnopedagogic and intercultural values.
\end{abstract}

Key Words: foreign language learning, hegemony, ethnopedagogy, intercultural learning 


\section{PENDAHULUAN}

Di awal tahun 2013, masyarakat di Indonesia terutama dunia pendidikan dikejutkan oleh berita yang menyebutkan bahwa Mahkamah Konstitusi (MK) membatalkan keberadaan Rintisan Sekolah Bertaraf Internasional (RSBI) dan Sekolah Bertaraf Internasional (SBI). Dalam amar putusannya, majelis hakim di MK menilai keberadaan RSBI/SBI telah menimbulkan perlakuan diskriminatif di dunia pendidikan sehingga dianggap bertentangan dengan prinsip konstitusi. (MK:RSBI kembali menjadi sekolah biasa, 2013). Hanya anakanak orang kaya saja yang bisa masuk ke RSBI karena biaya yang lebih tinggi dibanding sekolah reguler. Sudah menjadi rahasia umum, bahwa biaya yang dikenakan pada peserta didik yang akan bersekolah di RSBI/SBI sangat mahal untuk ukuran mayoritas masyarakat di Indonesia. Keberadaanya dianggap bisa melegalkan "kastanisasi" pendidikan.

MK menegaskan keberadaan

RSBI/SBI juga berpotensi menjauhkan dunia pendidikan dengan jati diri bangsa. Hal ini didasarkan pada fakta penggunaan bahasa asing yakni bahasa Inggris di setiap jenjang pendidikan (Alasan MK Bubarkan Sekolah RSBI, 2013). Pernyataan MK tersebut menimbulkan pertanyaan banyak pihak atau sebagian orang yang selama ini 'mengagungkan' pembelajaran bahasa Inggris (bahasa asing lainnya) yaitu apakah ada kaitanya antara pembelajaran bahasa asing dengan potensi berkurangnya jati diri sebagai bangsa Indonesia pada peserta didik di sekolah? Apakah hal itu mungkin terjadi?

Untuk menjawab pertanyaan tersebut haruslah dilakukan tilikan pada hakikat dan fungsi bahasa dalam kehidupan manusia. Bahasa merupakan entitas yang melekat pada diri manusia sejak dilahirkan di dunia. Keberadaan bahasa inilah yang membuat kehidupan manusia menjadi berbudaya.
Bahasa menjadi media pengembang pikiran manusia terutama dalam mengungkapkan realitas segala sesuatu. Alwasilah (2008:4) mengatakan bahwa bahasa merupakan alat untuk mengejawantahkan pikiran tentang fakta dan realitas yang direpresentasikan lewat simbol bunyi. Bahasa dan pikiran ini memiliki hubungan yang timbal balik, artinya bentuk bahasa yang digunakan akan dipengaruhi oleh pikiran manusia, sebaliknya bahasa dapat mempengaruhi cara berpikir manusia karena dibelakang bahasa 'berdiri' budaya.

Identitas atau jati diri seseorang akan terbentuk diantaranya melalui interaksi dengan bahasa dan budaya. Keduanya tak terpisahkan. Sebagai contoh peran bahasa ibu bagi perkembangan anak. Alwasilah (2012:84) menyebutkan bahwa "secara sosial dan kultural bahasa ibu adalah bahasa yang padat budaya". Ketika anak belajar bahasa dari ibunya untuk pertama kali, ia tidak hanya belajar satuan-satuan lingual yang bisa digunakan untuk berkomunikasi, tapi ia juga belajar kearifan yang terkandung dalam budayanya. Melalui bahasa ibu identitas kulturalnya akan dibentuk, termasuk pandangan hidup dan cara berpikirnya. Dari sini bisa dianalogikan bahwa pemerolehan bahasa asing - dalam konteks di sekolah disebut pembelajaran dapat membentuk (mengarahkan) identitas kultural dan cara berpikir seseorang. Dengan demikian kekhawatiran MK mengenai pembelajaran bahasa asing (Inggris) dari mulai TK - PT bisa menjauhkan anak didik dari jati dirinya sebagai bangsa Indonesia bisa dipahami. Bahkan ada yang mengkhawatirkan bahwa melalui pembelajaran bahasa asing itulah "penjajahan budaya" oleh barat dilakukan secara laten dibalik jargon globalisasi dan modernisasi.

Berkenaan dengan itu dalam artikel ini akan dikupas lebih jauh mengenai (1) 
bagaimana situasi pembelajaran bahasa asing di Indonesia?; (2) apakah benar bahwa melalui dunia pendidikan, terutama melalui pembelajaran bahasa asing, Barat dapat melakukan hegemoni terhadap Timur ?, dan; (3) solusi apa yang bisa ditawarkan untuk memperkokoh jati diri bangsa dengan tidak menghilangkan pembelajaran bahasa asing di sekolah?

\section{SITUASI PEMBELAJARAN BAHASA ASING DI INDONESIA}

Pembelajaran bahasa asing di Indonesia telah menjalani perjalanan sejarah yang panjang. Pada jaman kolonial, bahasa asing (seperti bahasa Belanda sebagai bahasa penjajah, serta bahasa Inggris dan Jerman) telah diajarkan di sekolah-sekolah tertentu, terutama di sekolah bagi keturunan para bangsawan dan anak-anak Belanda. Tak pelak, penguasaan terhadap bahasa asing di kalangan pribumi pada masa penjajahan Belanda menjadi penanda "kelas sosial" yang tinggi atau terhormat di masyarakat.

Seiring dengan perkembangan jaman, saat ini pembelajaran bahasa asing tidak lagi bersifat elitis. Semua orang bisa degan mudah mempelajarinya. Bahkan bahasa Inggris sudah mulai dikenalkan pada anakanak sejak usia dini. Hal ini dapat dibuktikan dengan adanya kelompok bermain ataupun Taman Kanak-Kanak yang sudah memberikan pelajaran bahasa Inggris pada anak-anak didiknya. Demikian pula pada jenjang sekolah dasar. Meskipun berdasarkan Permendiknas nomor 26 tahun 2006, bahasa Inggris mulai diajarkan pada tingkat sekolah menengah pertama. Pada jenjang sekolah menengah hingga perguruan tinggi, bahasa Inggris seolah menjadi suatu yang mutlak, berdampingan dengan mata pelajaran lain seperti bahasa Indonesia dan Matematika.

Bahasa asing lain selain bahasa Inggris, seperti bahasa Jerman, Prancis,
Jepang, Arab dan Mandarin pada umumnya dapat dipelajari ketika peserta didik masuk pada jenjang sekolah menengah atas. Posisi bahasa asing tersebut boleh dikatakan merupakan pelengkap. Yang utama tetaplah bahasa Inggris yang diakui sebagai bahasa Internasional.

Latar belakang yang menjadi dasar bagi pelaksanaan pembelajaran bahasa asing di berbagai tingkatan pendidikan dapat dipaparkan sebagai berikut. Pertama, sebagian besar ilmu pengetahuan dan teknologi di bidang apapun ditulis dalam bahasa Inggris atau bahasa asing lainnya, sehingga penguasaan bahasa Inggris atau bahasa asing lainnya akan memberikan jalan bagi bangsa Indonesia untuk menyerap perkembangan ilmu pengetahuan, atau menyebarkan ilmu pengetahuan yang berkembang di Indonesia. Kedua, masyarakat modern saat ini telah menjadi masyarakat dunia yang tak lagi tersekatsekat oleh jarak ataupun waktu berkat adanya kemajuan di bidang teknologi informasi dan transportasi. Masyarakat dunia berkembang menjadi masyarakat global yang nir-batas. Penguasaan bahasa asing akan menjadi pintu agar bangsa Indonesia bisa berinteraksi dalam masyarakat global. Aspek globalisasi ini menjadi salah satu pertimbangan mengapa bahasa Inggris dan bahasa asing lainnya perlu diajarkan di sekolah.

Kedua hal tersebut juga mengemuka dalam salah satu alasan rasional pengembangan Kurikulum 2013 yang disebut sebagai tantangan eksternal. Dalam Salinan Lampiran Permendikbud Nomor 69 tahun 2013 dijelaskan:

Tantangan eksternal antara lain terkait dengan arus globalisasi dan berbagai isu yang terkait dengan masalah lingkungan hidup, kemajuan teknologi dan informasi, kebangkitan industri kreatif dan budaya, dan perkembangan pendidikan di tingkat internasional... 
Atas dasar itu, maka bisa dipahami jika kompetensi dasar mata pelajaran bahasa Inggris untuk SMP dan SMA adalah mensyukuri kesempatan dapat mempelajari bahasa Inggris sebagai bahasa pengantar komunikasi internasional yang diwujudkan dalam semangat belajar. Ihwal globalisasi sebenarnya juga sudah disinggung dalam kurikulum sebelumnya. Misal dalam Standar Isi mata pelajaran bahasa Inggris untuk tingkat SMP/MTs disebutkan bahwa salah satu tujuan penyelenggaran mata pelajaran tersebut agar peserta didik " memiliki kesadaran tentang hakikat dan pentingnya bahasa Inggris untuk meningkatkan daya saing bangsa dalam masyarakat global". (Paket Pelatihan Kepala Sekolah: Standar Kompetensi dan Kompetensi Dasar, 2011). Hal serupa juga dijumpai pada mata pelajaran bahasa Asing lainnya seperti bahasa Jerman dan bahasa Prancis.

Ihwal globalisasi dan ilmu pengetahuan yang berkembang di dunia barat sebagai salah satu dasar mengapa bahasa asing perlu dipelajari di Indonesia, tentu tidak akan terlalu dipersoalkan jika pembelajaran bahasa asing merupakan variabel tunggal yang tidak disertai dengan variabel lain baik yang nyata terlihat maupun yang bersifat laten. Satu aspek penting terkait dengan hal itu adalah fakta bahwa bahasa melekat secara inheren pada budaya pemakainya. Dengan kata lain bahasa Inggris yang dipelajari oleh peserta didik melekat di dalamnya aspek kebudayaan Inggris (barat). Demikian pula bahasa Jerman, Prancis maupun Jepang. Hal inilah yang kemudian menjadi keresahan berbagai pihak di Indonesia, bahwa melalui pembelajaran bahasa asing peserta didik di semua tingkatan akan lebih memilih untuk mengarahkan orientasinya pada bahasa dan budaya asing. Ketercerabutan dari budaya sendiri (lokal) yang sejatinya harus menjadi identitas diri dikhawatirkan akan benarbenar terjadi.
Kekhawatiran tersebut bukannya tanpa dasar. Pada setiap institusi pendidikan selalu terjadi inkulturasi nilai-nilai, dan juga akulturasi budaya. Dalam konteks pembelajaran bahasa asing, akulturasi budaya Barat besar kemungkinan akan terjadi melalui proses belajar mengajar. Hal ini akan menjadi sangat berbahaya jika tidak disertai kesadaran yang kritis oleh pengajar dan peserta didik. Haruslah disadari bahwa institusi pendidikan merupakan tempat terjadinya pertarungan ideologi. Raymond Williams (dalam Santoso, 2011) menyebutkan bahwa karya sastra, filsafat, buku ajar (pelajaran), karya seni, sekolah, dan institusi budaya lainnya merupakan situs hegemoni, yakni tempat pertarungan ideologi berlangsung. Pada titik inilah patut dicurigai bahwa "barat" menggunakan politik kebudayaan - atau soft diplomacy untuk terus melakukan hegemoni terhadap bangsa-bangsa timur termasuk Indonesia. Salah satunya adalah dengan memanfaatkan jargon globalisasi dan modernisasi yang mensyaratkan kemampuan berbahasa Inggris atau bahasa asing lainnya. Terkait dengan hal itu kiranya perlu ditelusuri bagaimana hegemoni barat bisa berlangsung melalui pembelajaran bahasa asing.

\section{HEGEMONI "BARAT" TERHADAP "TIMUR" MELALUI PEMBELAJARAN BAHASA ASING}

Konsep hegemoni dimunculkan oleh Antonio Gramsci yang mengupas bagaimana kapitalisme bisa terus mendominasi dunia meskipun sering mendapat "serangan" dari aliran sosialis ataupun kiri. Pemikirannya dituangkan dalam sebuah buku berjudul The Prison of Notebooks. Gramsci sebenarnya tidak mendefinisikan secara jelas mengenai apa itu hegemoni. Meskipun demikian, hegemoni dapat dipahami sebagai perluasan dan pelestarian kekuasaan kelompok dominan (kelas penguasa) terhadap kelompok lain lewat kepemimpinan 
intelektual , moral dan politik, serta kebudayaan. Pelestarian kekuasaan ini diterima secara "sukarela" oleh kelompok yang didominasi. Menurut Eriyanto (2001: 104) ideologi hegemonic menyatu dan tersebar dalam praktik kehidupan, persepsi, dan pandangan dunia sebagai sesuatu yang dilakukan dan dihayati secara sukarela.Kekuatan yang hegemonik lebih banyak dilakukan bukan melalui kekuasaan bersenjata, namun justru lebih efektif melalui kekuatan politik dan kebudayaan.

Pemikiran Gramsci tentang hegemoni inilah yang kemudian menjadi salah satu pemicu pemikiran kritis Edward Said berupa kajian poskolonial. Pemikirannya telah menelanjangi usaha-usaha yang tidak terputus yang dilakukan barat untuk mendominasi (menjajah) timur, seperti yang tampak dalam bukunya Orientalisme. Said (1995:28) mengajukan sanggahan terhadap argumen-argumen yang mengatakan bahwa kebudayaan dan identitas nasional adalah entitas-entitas yang tunggal dan murni. Dengan melucuti pengertian "kita" dan "mereka" dari imperium, Said menunjukkan bagaimana asumsi-asumsi imperialis yang busuk terus mempengaruhi politik dan kebudayaan Barat. Dari sini kita bisa mencurigai bahwa imperialisme di era modern ini telah berubah wajah. Tidak lagi menunjukan wajah sangar dengan kekuatan senjata, namun "berwajah ramah" dalam bentuk invasi kebudayaan barat melalui berbagai cara dan media, seperti film, iklan, karya sastra, buku ajar, musik bahkan pembelajaran bahasa.

Dalam khasanah ilmu bahasa, saat ini dikenal dengan adanya istilah linguistic imperialism. Bahasa Inggris adalah salah satu pihak yang dituding sebagai pelaku imperialisme di bidang linguistik. Tak kurang seorang tokoh seperti Mahatma Gandhi pernah mengkhawatirkan adanya dominasi bahasa Inggris. Hal itu juga menjadi kekhawatiran beberapa anggota parlemen Eropa. Mereka prihatin bahwa kuasa bahasa Inggris atas ekonomi, ilmu pengetahuan, dan teknologi bisa jadi ancaman terhadap bahasa dan kebudayaan komunitas Eropa umumnya (Sastrodinomo, 2012). Dalam Konferensi Internasional Linguistik yang diselenggarakan ITB, British Council dan University of Leeds muncul gugatan dari Hywel Coleman OBE yang berpendapat bahwa dominasi bahasa Inggris menghadang upaya pemeliharaan keanekaragaman linguistik (Kompas, 27 Juni 2012).

Dominasi bahasa Inggris tidak hanya berdampak pada bahasa lain yang kemudian menjadi subordinat atau bahkan termaginalkan, melainkan juga berdampak pada aspek kebudayaan, seperti berkurangnya pemahaman dan penghargaan terhadap budaya sendiri. Dari paparan tersebut, sekali lagi kita menemukan bahwa kekhawatiran MK terhadap hilangnya jati diri anak bangsa karena penggunaan bahasa Inggris di dunia pendidikan tidaklah mengada-ada. Penggunaan bahasa Inggris yang terlalu dini bisa berpotensi mencerabut jati diri anak dari akar budaya lokalnya, terutama jika tidak disertai pemikiran yang kritis oleh orang tua dan pengajar bahasa Inggris.

Pertanyaan lanjutan yang kemudian muncul adalah, apakah pada peserta didik yang sudah beranjak remaja dan dewasa kemungkinan mengadopsi nilai-nilai kultural barat saat mempelajari bahasa tidak terjadi? Atau apakah mungkin ketercerabutan dari akar budaya lokal justru terjadi pada masa remaja atau dewasa?

Santoso dkk., pada tahun 2010 dan 2011 melakukan kajian mengenai dominasi barat yang tampak dalam buku ajar bahasa asing yaitu Inggris, Jerman dan Prancis. Kajian tersebut dilakukan dari sudut pandang poskolonial. Dari kajian tersebut ditemukan beberapa perwujudan dominasi barat. Berikut beberapa cuplikan dari hasil 
studi tersebut, terutama yang terkait dengan buku ajar bahasa Jerman dan Prancis.

Aspek superioritas Barat merupakan salah satu bentuk poskolonial yang banyak muncul dalam bentuk gambar yang menunjukan bahwa Barat (misal Jerman dan Prancis) memiliki aspek-aspek keunggulan dan modernitas dibanding Timur. Superioritas Barat dapat diartikan sebagai suatu visi subjek kolektif intelektual Barat dalam memarginalisasikan masyarakat timur. Di halaman 206 buku ajar bahasa Jerman Studio D Al terdapat slogan "Made in Germany”. Slogan ini sudah cukup lama dikenal yang mengisyaratkan bahwa produk Jerman memiliki kualitas baik. Pada situs www.germanoriganilty.com

disebutkan ".."Made in Germany" is recognized around the world as a label for products of high quality, standards and value...". Tak heran kepemilikan mobil mewah seperti BMW dan Mercedes-Benz kemudian menjadi simbol prestige dari pemilikinya. Penanda bahwa ia masuk dalam kelas menengah atas. Pada halaman 119 dalam buku ajar bahasa Prancis Campus

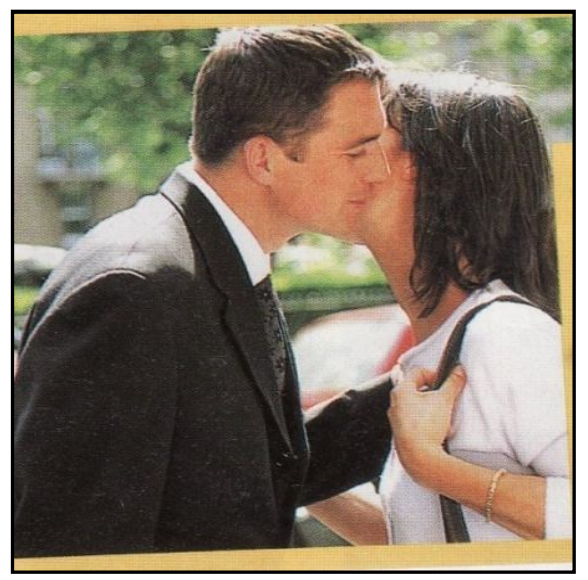

Gambar pertama menunjukkan seorang laki-laki dan perempuan saat bertemu melakukan cium pipi kiri dan kanan. Sedang gambar kedua menunjukkan penataan meja makan yang dianggap berskala internasional. Kedua hal tersebut saat ini banyak dilakukan oleh kalangan atas
1 tampak nama-nama perusahaan di Perancis dan Eropa yang sudah mendunia, seperti Danone, Carrefour, Nestlé, Philips dan Siemens. Superioritas Barat tampak jelas dengan hadirnya industri-industri Perancis dan Eropa tersebut di Indonesia. Tingginya antusiasme masyarakat dalam mengkonsumsi produk air mineral seperti Aqua yang merupakan lisensi dari Danone sudah sangat jelas. Pesatnya pertumbuhan pasar swalayan Carrefour di berbagai kota besar di Indonesia rasanya juga sulit untuk dibantah bahwa mereka telah menancapkan kukunya di sini. Perusahaan-perusahaan Eropa (Jerman dan Perancis) yang disebutkan di atas terbukti makin mengukuhkan bentuk superioritas Barat di Indonesia.

Bentuk poskolonialitas berikutnya adalah mimikri. Mimikri dapat dipahami sebagai bentuk-bentuk peniruan, penyesuaian terhadap etika dan kategori ideal Eropa, seolah-olah sebagai sesuatu yang universal (Ratna, 2008: 452). Hal ini tampak pada dua gambar yang diambil dari buku ajar bahasa Prancis.

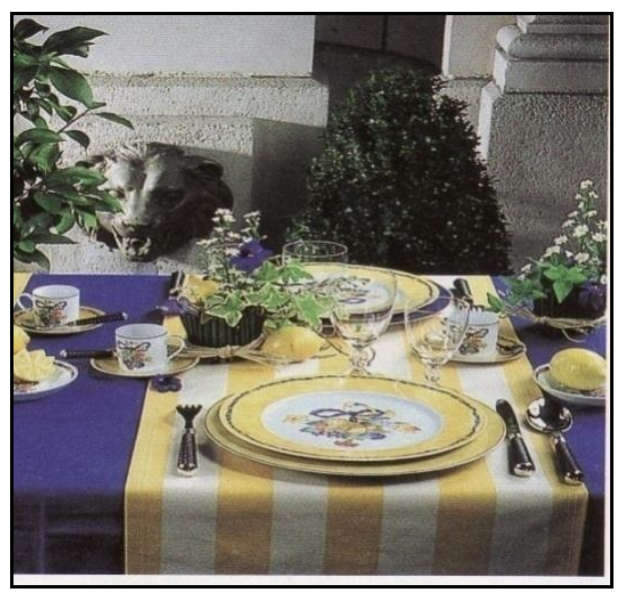

di

Indonesia, seolah menjadi penanda modernitas bagi mereka, meskipun sebenarnya tidak selalu cocok dengan budaya Indonesia.

Bentuk poskolonial lainya adalah apa yang disebut politik tubuh, sebuah bentuk 
perilaku untuk mengubah identitas tubuh seseorang dengan meniru identitas tubuh Barat. Dalam buku ajar bahasa Jerman aspek ini sangat tersamar dan terkait dengan salah satu produk Jerman yang sudah mendunia yaitu Nivea. Nivea adalah krim yang diproduksi untuk memelihara kejernihan kulit baik wanita maupun pria. Produk kosmetik yang dianggap bisa membuat kulit lebih bening ini banyak diminati oleh wanita Indonesia. Motiv seseorang untuk mengkonsumsinya, sering kali karena merasa kulit coklat tidaklah cantik sehingga perlu kosmetik tertentu yang dapat membuat kulitnya menjadi lebih bening / putih. Selama ini seolah berlaku anggapan bahwa cantik itu identik dengan kulit bening / putih, hidung mancung dan bermata biru. Simaklah bintang sinetron yang sangat laris, mereka adalah artis-artis yang umumnya memiliki darah campuran (Indo).

Aspek-aspek yang dipaparkan tersebut hanyalah sebagian contoh dari bagaimana berbagai unsur kebudayaan barat bisa meresap ke dalam budaya di Indonesia dan kerap menjadi acuan bagi masyarakat timur. Jawaban atas pertanyaan, apakah peserta didik usia remaja atau dewasa seperti mahasiswa bisa terkontaminasi budaya barat menjadi jelas, bahwa itu sangat mungkin terjadi jika tidak diiringi sikap kritis dan tidak dimilikinya fondasi budaya lokal yang kuat baik oleh peserta didik maupun pengajar bahasa asing. Beberapa contoh yang dipaparkan tersebut sekaligus juga menunjukan bagaimana budaya barat disisipkan pada pembelajaran bahasa asing sehingga bisa menunjang proses hegemoni Barat terhadap Timur.

Sadar akan hal itu, pihak barat tak segan-segan mengerahkan segala daya untuk membuka lembaga-lembaga kebudayaan mereka di seluruh dunia, seperti GoetheInstitut, British Council dan IFI-Institut Français d'Indonésie. Mereka juga tidak segan masuk pada dunia pendidikan di sekolah menengah atas untuk mengenalkan bahasa dan budaya mereka secara lebih dini, seperti yang dilakukan Jerman dengan program Partner Schule-nya (disingkat PASCH). Program ini merupakan bentuk kerjasama antara pemerintah Jerman dengan sekolah-sekolah di seluruh dunia yang menyelenggarakan pembelajaran bahasa Jerman. Sekolah yang terpilih akan memperoleh bantuan berupa pengembangan sumber daya manusia berupa pelatihan bagi guru bahasa Jerman di Jerman, perangkat pembelajaran, hingga pengiriman siswa berprestasi ke Jerman. PASCH hanyalah salah satu contoh. Hal serupa - meski dalam bentuk lain - juga dilakukan oleh negaranegara barat lainnya.

Tujuan yang ingin "ditembak" oleh pemerintah Jerman merupakan tujuan jangka panjang. Ini merupakan bagian dari strategi diplomasi yang bersifat lunak. Peserta didik yang sekarang belajar bahasa Jerman di SMA kelak akan menjadi pemimpin di Indonesia, setidaknya akan menjadi kelas menengah dan kelas atas. Mereka diharapkan akan memiliki orientasi ke Jerman, seperti kuliah di Jerman, membeli produk-produk Jerman, membuka investasi untuk Jerman, bekerja sama di berbagai bidang dengan Jerman dst. Jika diperhatikan, hal yang sama juga dilakukan oleh negara-negara yang secara ekonomi sudah sangat mapan, seperti Amerika, Inggris, Prancis, Jepang, Kanada dan sekarang perlahan adalah China.

Lalu apa yang bisa dilakukan oleh bangsa Indoneisa? Apakah pembelajaran bahasa asing yang dicurigai menjadi saran hegemoni barat harus dihapus? Tentu saja tidak. Pembelajaran bahasa asing tetap dapat diselenggarakan berdampingan dengan pembelajaran bahasa Indonesia atau daerah. Salah satu cara yang ditawarkan di sini adalah menggunakan konsep etnopedagogik dan pembelajaran bahasa yang berbasis pada pendekatan interkultural. 


\section{ETNOPEDAGOGI DAN \\ PEMBELAJARAN BAHASA ASING BERWAWASAN INTERKULTURAL}

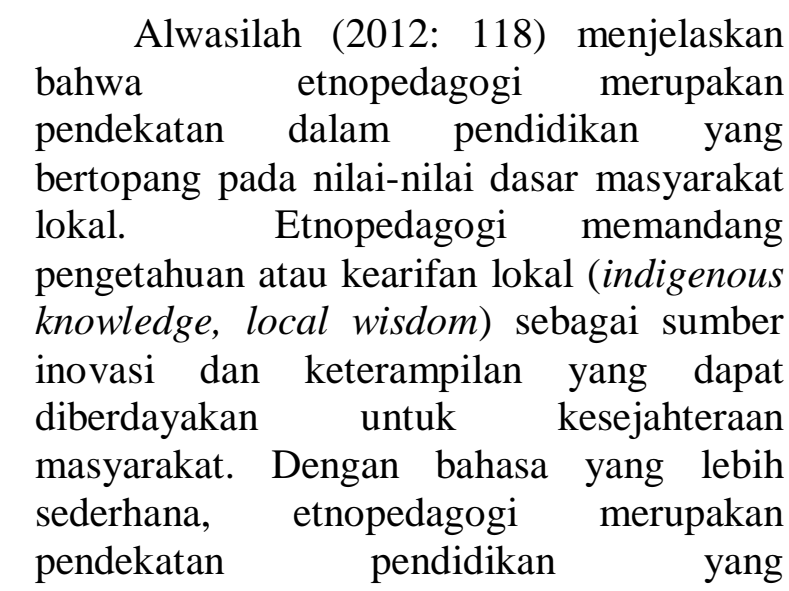
mengintegrasikan kearifan lokal dalam praksisnya. Kearifan lokal ini kemudian menjadi napas bagi seluruh unsur-unsur pendidikan yang terlibat di dalamnya, mulai dari kurikulum, proses belajar mengajar hingga evaluasinya.

Praksis pendidikan yang menggunakan pandekatan etnopedagogi pada dasarnya merupakan upaya untuk menjaga agar peserta didik tidak tercerabut dari akar budayanya karena memahami dengan baik kearifan lokal yang dimiliki masyarakatnya. Etnopedagogi juga membekali peserta didik dengan kemampuan mengantisipasi perkembangan dunia yang berubah dengan cepat. Praksis pendidikan yang bernuansa etnoepdagogi membekali peserta didik dengan fondasi budaya lokal yang kuat.

Praksis pendidikan seperti ini harus dimulai dengan menggali kembali kekayaan budaya lokal untuk menemukan bentukbentuk kearifan lokal. Berdasarkan karifan lokal yang ditemukan tersebut, proses pembelajaran dapat dirancang. Dalam pembelajaran bahasa asing misalnya, peserta didik dapat dikenalkan dengan cerita rakyat (sastra lokal) yang ditulis dalam bahasa asing yang dipelajari. Seandainya tidak ditemukan cerita rakyat yang sudah ditulis dalam bahasa asing, peserta didik dapat diminta untuk menuliskan kembali cerita rakyat ke dalam bahasa asing. Proses penulisan kembali ataupun pembacaan cerita rakyat dalam bahasa asing yang dipelajari harus disertai dengan analisis kritis untuk menemukan nilai-nilai positif yang terkandung di dalamnya.

Dari sisi didaktik dan metodik, proses belajar mengajar bahasa Asing selalu mengikutsertakan upaya untuk mengenal dan memahami latar belakang budaya dari bahasa yang dipelajari. Kompetensi komunikatif yang dicanangkan untuk diraih dalam pembelajaran tersebut akan sulit terealisir, jika peserta didik tidak mengenal budaya dari bahasa asing tersebut. Menurut Canale dan Swain (dalam House, 1997) upaya untuk meraih kompetensi komunikatif secara komprehensif akan tercapai jika peserta didik disamping mengusai unsurunsur kebahasaan juga memahami konteks kultural yang menjadi latar belakang perkembangan sebuah bahasa. Oleh karena itu pada saat-saat tertentu pengajar bahasa harus menjelaskan aspek budaya dari bahasa yang diajarkannya.

Dalam situasi seperti itu pengajar harus bersikap kritis, karena seringkali dijumpai aspek budaya yang menyertai sebuah ujaran kebahasaan tidak sesuai dengan nilai-nilai budaya lokal. Sebagai contoh ungkapan bahasa Inggris yang sering kita dengar yaitu "Time is money". Jika direnungkan ungkapan tersebut cenderung mendorong manusia untuk memanfaatkan waktu seefisien mungkin demi mengejar sesuatu yang bersifat materi. Jangan dilupakan ungkapan tersebut datang dari negara industri yang memiliki latar belakang budaya kapitalis. Ungkapan ini agak berbeda nuansanya dengan misalnya pepatah Jawa yaitu alon-alon asal kelakon (Pelan-pelan asal terlaksana/tercapai). Dalam pepatah tersebut mengandung pesan agar kita tidak tergesa-gesa, sabar dan hati-hati. Demikian 
pula kalimat bahasa Jerman yang dijumpai dalam sebuah teks di buku ajar bahasa Jerman yang berbunyi Sie ist ledig, aber hat ein Kind (Dia lajang, tapi punya satu anak). Latar belakang budaya yang dapat digunakan untuk menjelaskan fenomena tersebut adalah "dia lajang dan mengadopsi anak" atau "dia lajang, tapi sudah punya anak di luar pernikahan”. Dalam konteks budaya Jerman, yang sering terjadi adalah kemungkinan kedua. Hal-hal seperti inilah yang perlu dikritisi oleh pengajar dan peserta didik berbekal kearifan lokal. Selain itu pengajar jangan sampai terjebak pada sikap yang cenderung 'mengagungkan' budaya barat. Dalam teks-teks yang ada pada buku ajar asing yang diterbitkan di negara asalnya, selalu dimunculkan wacanawacana yang merekam perkembangan kehidupan masyarakatnya, seperti kemajuan teknologi, kemapanan di bidang ekonomi, kesejahteraan, industri yang maju dll.

Sebuah pendekatan dalam pembelajaran bahasa asing yang saat ini berkembang - terutama di negara-negara Eropa - adalah pendekatan interkultural. Pendekatan ini memiliki landasan bahwa sebenarnya keberhasilan komunikasi yang terjadi antar dua komunikator yang berasal dari dua budaya berbeda tidak hanya ditentukan oleh penguasaan aspek kebahasaan, baik struktur gramatikal maupun sosio-pragmatiknya, tetapi juga kemampuan menangkap, memahami dan memiliki empati terhadap kultur partner komunikasinya. Oleh karena itu tujuan yang ingin dicapai bukan hanya kompetensi komunikatif, melainkan juga kompetensi interkultural. Kompetensi interkultural merupakan kompetensi yang dimiliki oleh seseorang untuk berinteraksi dengan orang yang berasal dari kultur lain dengan berpegang pada kemampuan untuk menghargai budaya sendiri (the self) serta empati terhadap budaya asing (the other). Menurut Weimann dan Hosch (dalam
Pauldrach, 1992) tujuan global dari komunikasi interkultural adalah untuk memberikan kontribusi dalam pemahaman antar bangsa. Dengan demikian pengajar bahasa asing harus mampu mengantarkan peserta didiknya untuk dapat memahami budaya asing yang terepresentasikan dalam bahasanya dengan berpegang pada pemahaman atas budaya sendiri. Di sinilah ditemukan kesesuaian antara pendekatan interkultural dalam pembelajaran bahasa asing dengan pendekatan etnopedagogik.

\section{SIMPULAN}

Keberadaan pembelajaran bahasa asing di Indonesia adalah suatu keniscayaan. Penguasaan terhadap bahasa asing sangat diperlukan, karena beberapa alasan. Pertama, penguasaan bahasa asing merupakan pintu masuk untuk memasuki masyarakat dunia yang global (gloablisasi). Kedua, sebagai sarana untuk menyerap ilmu pengetahuan yang berkembang di negaranegara lain dan sebaliknya menjadi media untuk menyebarkan ilmu pengetahuan yang berkembang di Indonesia ke luar. Kedua alasan tersebut tentu sangatlah baik untuk dipegang. Meskipun begitu bangsa Indonesia harus tetap bersikap kritis, karena pembelajaran bahasa Asing bisa menjadi 'kendaraan' pihak Barat untuk melakukan hegemoni terhadap Indonesia.

Dalam konteks pembelajaran bahasa asing, kemungkinan terjadinya perubahan pola pikir dari peserta didik yang belajar bahasa asing sangatlah mungkin. Bahasa mencerminkan pola berpikir masyarakat penuturnya, sehingga ketika terjadi proses pembelajaran bahasa asing secara tidak langsung terjadi pula proses persingunggan dengan pola pikir serta budaya bangsa yang bahasanya dipelajari. Pada saat itu wawasan kultural peserta didik bisa berubah. Perubahan tersebut bisa dalam bentuk pengabaian terhadap budaya sendiri atau pemujaan yang berlebihan terhadap budaya asing tersebut. 
Ada dua jalan yang bisa ditempuh sebagai solusinya. Pertama, menerapkan pendekatan etnopedagogi pada pembelajaran bahasa asing. Melalui etnopedagogi kita akan selalu 'menoleh' pada kearifan lokal yang dimiliki bangsa Indonesia, sehingga kekhawatiran akan tercerabutnya jati diri sebagai bangsa Indonesia bisa dieliminir. Kedua, menerapkan pendekatan interkultural dalam pembelajaran bahasa asing. Pendekatan interkultural bertujuan untuk mengembangkan kompetensi komunikatif dan interkultural pada diri pembelajar. Kompetensi interkultural merupakan kemampuan berempati terhadap budaya asing dengan berlandaskan pada budaya sendiri.

\section{UCAPAN TERIMA KASIH}

Ucapan terima kasih secara khusus penulis sampaikan kepada Panitia Forum Ilmiah IX (Seminar dan Lokakarya Internasional Bahasa, Sastra, Seni dan Pembelajarannya) FPBS UPI yang telah memberi kesempatan pada penulis untuk menyajikan artikel ini. Terima kasih juga disampaikan kepada Prof. A. Chaedar Alwasilah, M.A., Ph.D yang telah memperkenalkan etnopedagogi dalam perkuliahan yang beliau ampu di Sekolah Pascasarjana UPI.

\section{PUSTAKA RUJUKAN}

Alwasilah, A.Chaedar. 2008. Filsafat Bahasa dan Pendidikan. Bandung: Penerbit PT. Remaja Rosdakarya.

---------.2012. Pokoknya Rekayasa Literasi. Bandung: PT. Kiblat Buku Utama.

Alasan MK Bubarkan Sekolah RSBI. (8 Januari 2013). Tribun News.com. Diakses dari http://www.tribunnews.com/nasion al/2013/01/08/alasan-mk- bubarkan-sekolah-rsbi, pada tanggal 8 Oktober 2013.

Eriyanto. 2001. Analisis Wacana, Pengantar Analisis Teks Media. Yogyakarta: Penerbit LKiS.

House, Juliane. 1997. "Zum Erwerb interkultureller Kompetenz im Unterricht des Deutschen als Fremdsprache" in Zeitschrift für interkulturellen

Fremdsprachenunterricht (Online). Jahrgang 1, Nummer 3, Januari 1997. Diakses dari http://zif.spz.tudarmstadt.de/jg-01-

3/beitrag/house.htm pada tanggal 9 Pebruari 2013.

MK: RSBI kembali menjadi sekolah biasa.(8 Januari 2013). Merdeka.com. diakses dari http://www.merdeka.com/peristiwa/ mk-rsbi-kembali-menjadi-sekolahbiasa.html pada tanggal 9 Pebruari 2013.

Paket Pelatihan Kepala Sekolah: Standar Kompetensi dan Kompetensi Dasar, 2011. Diakses dari http://inovasipendidikan.net/ppks/P aket\%20Pelatihan\%20Kepala\%20S ekolah\%20(Standar\%20Kompetensi ).pdf, pada tanggal 9 Pebruari 2013

Pauldrach, Andreas. 1992. "Eine unendliche Geschichte: Anmerkungen zur Situation der Landeskunde in den90er Jahren" in Fremdsprache Deutsch - Zeitschrift für den Praxis des Deutschunterrichts: Landeskunde. Juni, 1992. München: Verlag Klett Edition Deutsch.

Peran Bahasa Inggris digugat. Kompas, tanggal 27 Juni 2012.

Peraturan Menteri Pendidikan Nasional, Nomor 26 tahun 2006, diakses dari http://akhmadsudrajat.files.wordpres 
s.com/2009/04/permendiknas-no-22tahun-2006.pdf pada tangal 12 Pebruari 2013.

Ratna, Nyoman Kutha. 2008. Poskolonialisme Indonesia, Relevansi Sastra. Yogyakarta: Pustaka Pelajar

Said, Edward. 1995. Kebudayaan dan Kekuasaan: Membongkas Mitos Hegemoni Barat. Bandung: Mizan.

------------. 1994. Orientalisme. Bandung: Penerbit Pustaka

Salinan Lampiran Peraturan Menteri Pendidikan dan Kebudayaan, Nomor 69 Tahun 2013 Tentang Kerangka dasar dan Struktur Kurikulum Sekolah Menengah Atas/Madrasah Aliyah. Diakses dari http://bsnp- indonesia.org/id/bsnp/wpcontent/uploads/2013/06/SalinanPermendikbud-No.-69-th-2013-ttgttg-KD-dan-Struktur-KurikulumSMA-MA.zip pada tanggal 9 Oktober 2013.

Santoso, Iman., Nurhadi, Swandayani, Dian., \& Nurhayati, Ari. 2011 Bentuk-bentuk Dominasi Barat Mutakhir di Indonesia: Kajian Poskolonial terhadap Textbook Universitas, Karya Sastra, dan Pemikiran Barat. Laporan Penelitian Hibah Stranas, DP2M Dikti.

Sastrodinomo, Kasijanto. "Melawan Dominasi Bahasa Inggris”. Dikutip dari Kompas, 27 April 2012. 